\title{
How to describe "the world of colossal absurd"? On the grotesque in Gulag literature
}

Tadeusz Borowski concluded his reflection in $U$ nas, w Auschwitzu... on everyday issues with a statement which is often quoted (though without sufficient understanding) in various studies regarding the theme of camp reality: "but it is false and the grotesque, like the whole camp, like the whole world". ${ }^{1}$ One should see in it not so much a gloss to the "personal" confession of Abramek the Jew explaining the new method of burning in the stack ("you take four kids with hair, press their heads together, and light the hair. Then everything burns just like that, and everything is gemacht'); nor a comment to his excuses evoked by the not so enthusiastic reaction of the narrator to the ideas for improvements by the Sonderkommando ("here in Auschwitz, we play like we can. As if you could endure otherwise"), ${ }^{2}$ as a reflection on the entire Lager universe, which combined extermination with play, and cruelty with a joke. The grotesque - surely, but is it necessarily untrue?!

It is possible that Borowski did not know the concept of the grotesque as an aesthetic category as we use it today, yet that does not mean that it was a term which meant the same as for an ordinary user of Polish. Andrzej Trzebiński, one of his closest friends from secret Polish classes, ${ }^{3}$ a theoretician and practician of the grotesque, understood it as a "laughter of strangeness", but also as a "genre which achieves the maximum objectivity", which "uses objective conventions resulting from internal meaning". "Therefore, the author of Aby podnieść różę

* Associate Professor; Institute of Polish Studies, Faculty of Philology and History, Pomeranian University in Słupsk; tsucharski@wp.pl.

${ }^{1}$ T. Borowski, “U nas, w Auschwitzu...”, in: ibid., Utwory wybrane, A. Werner (ed.), Zakład Narodowy im. Ossolińskich, Wrocław - Warsaw - Krakow 1991, p. 122 [BN I 276]. [English version translated from Polish]

${ }^{2}$ Ibid.

${ }^{3} \mathrm{~T}$. Borowski reminisced about Trzebiński and their student days with emotion and sympathy in several texts: Matura na Targowej, Profesorowie i studenci and, finally, Portret przyjaciela. Trzebiński's opinions of his colleague were much more reserved, vide: A. Trzebiński, "Pamiętnik", in: ibid., Kwiaty z drzew zakazanych. Proza, introduction and editing Z. Jastrzębski, Instytut Wydawniczy PAX, Warsaw 1972, p. 103, 142.

${ }^{4}$ A. Trzebiński, "Pamiętnik", op. cit., p. 197. 
saw in the grotesque an opportunity for reaching objectivity. It is impossible that Borowski was not familiar with such an understanding, which is why in the final words of $U$ nas, $w$ Auschwitzu... one probably should identify a record of a type of psychomachia, internal dilemmas of Borowski, man and artist, as those words proved the author's basically exclusive understandings of the term the grotesque. The fact of combining it with falseness, and in a coordinating relation, would suggest the application of its meaning as an exaggerated nonsense, incoherence, or even absurd, in the common understanding of the word. The combination of extermination with play, then, perfectly aligns with the understanding of the grotesque as a "set of harmonised dissonances". Being one of the internees of KL Auschwitz, he saw in Abramek's (and others like him) boastings and methods "pointless crimes, oddities the grotesque terror of which had nothing to do with humanity". ${ }^{6} \mathrm{He}$ fought heroically to remain true to pre-Auschwitz values, he deadened the anti-principles of the camp world with an arch-human conviction of its "falseness", yet as an artist, witness, and the narrator of that reality, he understood that the grotesque is the best form of expression for absolutely incomprehensible experiences, for extremes, dissonances, antitheses, and contradictions which he experienced, and which he witnessed in Auschwitz. He understood that the camp was a Betrugslager, "camp of deceit", he saw the grotesque disproportion between the propaganda façade and the reality of the camp world (the slogan over the gate, the bath, music, the overture to Tancredi, the wedding). That was why after the humanistic story Unas, $w$ Auschwitzu... it was time for brutal, "inhuman" works, the nature of which was already indicated in the title of This Way for the Gas, Ladies and Gentlemen, rather grotesque than ironic.

Borowski's dilemmas offer perfect examples for the frequently expressed conviction that there could not be a more problematic literary term than the grotesque. Lee Byron Jennings, having studied various examples of the application of the noun the grotesque and the related adjective grotesque, as well as their dictionary definitions, in the language of American newspapers, was inclined to yield to the "temptation to avoid any attempts at defining that term," since there have been as many such attempts as there have been those who wrote on it. However, one could try to find, particularly for the purposes of reading camp literature, specifically complementary elements, even in mutually exclusive concepts. In one of the most important and earliest concepts of the grotesque in the $20^{\text {th }} \mathrm{c}$., Wolfgang Kayser argued that the grotesque is terrifying atrocity based on play with the absurd; he also argued that the grotesque is a familiar world which suddenly

${ }^{5}$ M. Głowiński, “Groteska jako kategoria estetyczna”, in: Groteska, M. Głowiński (ed.), słowo/obraz terytoria, Gdańsk 2003, p. 9.

${ }^{6}$ E. A. Poe, "Zabójstwo przy rue Morgue”, in: ibid., Opowieści niesamowite, trans. S. Wyrzykowski, Wydawnictwo Literackie, Krakow 1976, p. 194; vide also: L. B. Jennings, "Termin «groteska»", in: Groteska, op. cit., p. 177 [footnote].

${ }^{7}$ L. B. Jennings, op. cit., p. 38. 
becomes hostile and alienated, subjected to the influence of $E s$, i.e. an impersonal internal force, an inhuman element. ${ }^{8}$ Mikhail Bakhtin entered into a polemic with Kayser's concept in Rabelais and His World, where he rejected mainly the element of terror, alienation, and inhumanity ("das Unheimliche") stressed by the German researcher. According to the Russian formalist, the carnival sensation of the world is the true nature of the grotesque. Kayser's inhuman Es was replaced in Bakhtin's concept with a cheerful "funny monstrosity". ${ }^{9}$ Lee Byron Jennings's work could be considered an attempt at reconciling both concepts, though he did not mention Bakhtin. For the American researcher, the grotesque was a close combination of a funny and innocent element with the element which is atrocious, terrifying, and menacing: "atrocity is treated humorously, and is presented as being funny". ${ }^{10}$ For the grotesque to emerge, according to Jennings, one must be convinced that "we are truly facing something which we would normally consider impossible". ${ }^{11}$ That "definition" must be supplemented with the exceptionally important remarks by Michał Głowiński, who apart from the grotesque's vision of the world, saw in it an appeal to the "dominant social awareness. An appeal through negation". ${ }^{12}$ And that proposition is worth remembering, particularly in the context of reading texts reproducing camp reality.

In the most extensive study in the $20^{\text {th }}$ century Polish literature devoted to the grotesque, Włodzimierz Bolecki did not attempt to define it, yet he did discuss the ways in which it appears in Polish literature. According to him, the most important stage in the history of Polish grotesque was the temporal shift in the Young Poland period of "grotesque motifs from the level of large verbal arrangements to the level of stylistic actions". Bolecki identified two types of such actions: "the first consists of various instances of disillusion", which he understood as satirical-pamphlet narration, mocking the created characters, a humorous attitude towards descriptions, play on words, charades, meta-narrational digressions, while the other included "various parodies revealing the inter-textual status of literature". ${ }^{13}$ Equipped with a compass, he sailed the archipelagos of grotesque texts and motifs in $20^{\text {th }}$-century Polish literature. Yet he carefully avoided the reefs of camp literature.

Reefs indeed because, as Sławomir Buryła noted aptly, regardless of the increasingly pestering "conviction" about the "lack of a monographic study holistically

${ }^{8}$ W. Kayser, "Próba określenia istoty groteskowości”, in: Groteska, op. cit., pp. 23-24.

${ }^{9}$ M. Bachtin, Twórczość Franciszka Rabalais'go a kultura ludowa średniowiecza i renesansu, trans. A. and A. Goreń, S. Balbus (ed.), Wydawnictwo Literackie, Krakow 1975, pp. 112-113. [English version translated from Polish]

${ }^{10}$ L. B. Jennings, op. cit., p. 55.

${ }^{11}$ Ibid., p. 46.

${ }^{12}$ M. Głowiński, op. cit., p. 10.

${ }^{13}$ W. Bolecki, "Groteska, groteskowość", in: Stownik literatury polskiej XX wieku, editorial team: A. Brodzka, M. Puchalska, M. Semczuk, A. Sobolewska, E. Szary-Matywiecka, Zakład Narodowy im. Ossolińskich, Wrocław - Warsaw - Krakow 1992, p. 350. 
discussing the relationship between war and the grotesque", the pressure of the "incongruity of the topic itself, which somewhat naturally demands different means of expression, and of the heaviness of the Romantic traditions" still proves stronger. ${ }^{14}$ But that ascertainment proves the important evolution in the thinking about the study and interpretation of the formulas for expressing wartime/camp experiences. Over half a century ago in a review of Jasetka-moderne by Ireneusz Iredyński, Marta Piwińska subtly yet firmly suggested that "there may be issues which do not need to be announced, experiences which are better left uncommunicated, and opportunities which should rather be covered with silence". ${ }^{15}$ That warning, surprising in itself for a literary researcher, was even more astonishing since then there already existed works which opposed that tabooisation. The suggestion was, however, directed at researchers rather than writers. Almost parallel to Piwińska, Jan Błoński appreciated the efforts of Iredyński, Stanisław Grochowiak, and Bohdan Drozdowski who were all focussed on the "theatre of tragic grotesque, which seems to express our times and experiences best". ${ }^{16}$ Those words resonated with Friedrich Dürrenmatt's stipulations that in the case of "the disappearance of individual guilt", and the dwindling of the "sense of measure necessary for tragedy", "in order to create any pretence of a face for our century without any face, and full of paradoxes, we must resort to tragicomedy and the grotesque". ${ }^{17}$ Despite those suggestions, the majority of literary researchers of the century of the disgrace of totalitarian captivity submitted rather to Piwińska's thesis rationalising that renunciation with the not entirely legitimate conviction that "in Polish literature discussing war and occupation, the grotesque does not possess a significant presence". ${ }^{18}$ In the study referred to above, Buryła indicated only some works in which he found "temporarily" or "textually limited" 19 attempts at analysing it. He included the works by Jerzy Święch, and Zdzisław Jastrzębski, and a book by Iwona Mityk, ${ }^{20}$ which almost completely omitted camp texts, and Gulag-related texts completely. The most recent studies, the works by Arkadiusz Morawiec devoted to the output of Marian Pankowski in particular, constitute a glimmer of hope that ethical dilemmas have been overcome, ${ }^{21}$

${ }^{14}$ S. Buryła, "Nobilitacja groteski”, Teksty Drugie 2006, issue 4, p. 129.

${ }^{15}$ M. Piwińska, "Jasełka - moderne”, Dialog 1963, issue 3, p. 118.

${ }^{16}$ J. Błoński, "Między szyderstwem a okrucieństwem”, Dialog 1963, issue 4, p. 74.

${ }^{17}$ L. B. Jennings, op. cit., p. 31.

${ }^{18}$ S. Buryła, op. cit., p. 129.

${ }^{19}$ Ibid.

${ }^{20}$ Z. Jastrzębski, "Wymiary groteski”, in: ibid., Literatura pokolenia wojennego wobec Dwudziestolecia, IBL, Warsaw 1969; J. Święch, "Surrealizm i groteska", in: ibid., Literatura polska w latach II wojny światowej, Wydawnictwo Naukowe PWN, Warsaw 1997; I. Mityk, Inne spojrzenie. Groteska w prozie polskiej o wojnie i okupacji. Gombrowicz, Dygat, Sandauer, Andrzejewski, Zieliński, WSP Kielce 1997.

${ }^{21}$ A. Morawiec, "Tematyka lagrowa w twórczości Mariana Pankowskiego", in: Język - literatura - dydaktyka, vol. 2, R. Jagodzińska and A. Morawiec (eds.), Wydawnictwo Wyższej Szkoły Humanistyczno-Ekonomicznej, Łódź 2003, p. 26. 
though the author emphasised that the manner of approaching camp reality by the author of $Z$ Auszwicu do Belsen "in many respects exceeds that which readers are used to, i.e. stereotypes associated with Lager literature". ${ }^{22}$

In the texts mentioned above, one should, however, notice small contributions, which are far from holistic studies of the "protected" space of Lager literature, a completely omitted territory of Gulag literature. It is high time to start filling in the blanks bearing in mind, though, the extremely sound warning by Józef Kelera that "the decision whether a given phenomenon «already is» grotesque or «it is not yet» has to be made arbitrarily, or even intuitively to some extent, which can and does cause various controversies". ${ }^{23}$

In certainly the most important attempt at offering a synthetic and a parallel study of literary texts devoted to the experiences of Nazism and Soviet communism, in the "camp literature" entry included in Stownik literatury polskiej $X X$ wieku, Lidia Burska identified four streams of camp literature approached as a whole. In the final group she included works in which she identified attempts at "distancing the experiences through satire or the use of the category of the absurd" ${ }^{24}$ There, however, unlike the researchers I have mentioned before, she stressed the significance of that descriptive formula only, rather surprisingly, in Gulag literature, and she provided as examples of that Zapiski oficera Armii Czerwonej by Sergiusz Piasecki (which has nothing to do with a gulag) and Budujemy kanat by Witold Olszewski (Stanisław Kempiński). While, in fact, the grotesque appears in all "variations" of camp literature. Apart from the already mentioned works by Pankowski, one must refer to Pięć lat kacetu by Stanisław Grzesiuk; novels: Trismus by Stanisław Grochowiak, Wózek by Janusz Krasiński; stories by Kornel Filipowicz, or the most shocking fragments of Obóz Wszystkich Świętych by Tadeusz Nowakowski, in which, as the emigre historian wrote, "even the inhabitants of the camp resembled characters from Daumier's (if not Goya's) paintings". ${ }^{25}$ The last novel, just like Bitwa pod Grunwaldem by Tadeusz Borowski, also proved that the grotesque appears in DP literature.

The attempts at altering the focus of the study of camp literature are surely increasingly connected with the fundamental change in the formula (or even resulting from it) of presenting the camp world, though actually the texts which are the subject of my study were created much earlier, the first ones just after WWII. Berel Lang posited that "even the most rudimentary act of writing" about the Nazi genocide is "obliged to represent in its own means the measure of that moral

${ }^{22}$ Ibid.

${ }^{23}$ J. Kelera, "Groteski dramaturgia", in: Stownik literatury polskiej XX wieku, op. cit., pp. 361-362.

${ }^{24}$ L. Burska, "Obozowa literatura", in: Stownik literatury polskiej XX wieku, op. cit., p. 746.

${ }^{25}$ Z. Markiewicz, "Proza beletrystyczna”, in: Literatura polska na obczyźnie 1940-1960. Collective work published through the initiative of the Polish Writers' Association Abroad, T. Terlecki, B. Świderski (eds.), London 1964, vol. 1, p. 161. 
enormity". ${ }^{26}$ For many years, though, there did not exist the readers', or, considered more broadly, receptive, consent to any "means" not sufficiently "worthy", applied, of course, both by literature and other culture texts. ${ }^{27}$ A perfect Polish example would be the lesser known output of Marian Pankowski, absent in the readings and the awareness of a wider circle of readers, starting with his novel Matuga idzie. Przygody, through Teatrowanie nad świętym barszczem, until his final text, the crowning of his camp "brawl" 28 entitled Z Auszwicu do Belsen. Similar, though not to such an extent and with a happy ending, was the reaction of non-Polish readers to the rather serious Fateless by Imre Kertész, who later won the Nobel Prize. ${ }^{29}$ A different fate befell the part of Art Spiegelman's graphic novel entitled Maus. A Survivor's Tale ${ }^{30}$ devoted to Auschwitz, for which he won the 1992 Pulitzer Prize. The author himself was uncertain whether a graphic novel is a form worthy of raising such a topic. But he probably made inroads for another formula of talking about the Holocaust. For the last decade or so one could have observed a certain shift in the area, Life Is Beautiful by Roberto Benigni being the perfect example of that. ${ }^{31}$ Slavoj Žižek was extremely apt in noting that the success of Benigni's film "set off a new sub-genre: Holocaust-related comedy", seeing the main cause of its birth in the "obvious failure of tragedy". ${ }^{32}$ Radu Mihaileanu with his Train of Life joined that stream..$^{33}$ The Romanian director admitted that the

${ }^{26}$ B. Lang, Nazistowskie ludobójstwo. Akt i idea, trans. A. Ziębińska-Witek, Wydawnictwo UMCS, Lublin 2006, p. 132. [English version: Lang, B. Act and Idea in the Nazi genocide. Syracuse 2003]

${ }^{27}$ P. Czapliński ("Zagłada jako wyzwanie dla refleksji o literaturze", Teksty Drugie 2004, issue 5, p. 22 [footnote]) posited "that Shoah, like no other experience, belongs to tragicness, and like no other is subject to comicality." Yet he added: "One can, however, view the task of art after Shoah as recovering everything of which its originators tried to deprive the victims - both the variety of experiences and their mixing."

${ }^{28}$ M. Pankowski referred as "brawl" (P. Marecki, Nam wieczna w polszczyźnie rozróba! Marian Pankowski mówi, Korporacja Halart, Krakow 2011, p. 230) to "an act of transgression, transcending the existing literature, one's own Polishness". A sentence from the quoted book appeared in the conclusion of the "To the Reader" chapter, opening the novel Matuga idzie. Przygody.

${ }^{29}$ J. Jastrzębska ("Imre Kertész - węgierski wariant dyskursu o Holocauście”, Teksty Drugie 2004, issue 5, p. 156) stressed that the author himself complained about it with "exaggeration".

${ }^{30}$ A. Spiegelman, Maus. Powieść ocalałego. Cz. II I tu zaczęty się moje kłopoty, trans. P. Bikont, Wydawnictwo Komiksowe, Krakow 2001, p. 16. [Spiegelman, A. Maus II. A Survivor's Tale. New York 1991] "Sigh. I feel so inadequate trying to reconstruct a reality that was worse than my darkest dreams. And trying to do this as a comic strip! I guess I bit off more than I can chew". p. 45. Holocaust survivor: "Take a look how many books have already been written on Shoah. And what for? Did people become better thanks to that?... Maybe they need a new bigger extermination? Either way, the victims are dead, and they can't say anything from their point of view, so maybe no more stories are needed".

${ }^{31}$ P. Czapliński defined (op. cit., p. 12) the scene of interpreting the orders of an SS officer by Guido, the main protagonist, as "almost burlesque" in nature.

${ }^{32}$ S. Žižek, "Komedia obozowa", trans. Adam Chmielewski, Teksty Drugie 2004, issue 5, p. 135.

${ }^{33}$ T. Sobolewski ("Archiwum Spielberga”, Kino 1998 issue 10, p. 62) called Mihaileanu’s film a "beautiful and wise fairy tale". 
film about the "self-deportation" project of a shtetlekh was inspired by Schindler's List by Steven Spielberg, which he received with ambivalent feelings. The film was certainly emotional, yet it also proved that a certain form of expression was exhausted, and that one can no longer tell the story of the tragedy of Jews only within an aura of martyrdom. ${ }^{34}$

Such dilemmas, doubts and resulting suppressions, somewhat resulting from social or psychological considerations, but most of all from quasi or rather pseudo-axiological considerations, could, on the one hand, discourage people from reflecting on the grotesque in camp literature, while, on the other, they perversely provoke one to examine the matter closely, to cross the threshold of tabooisation. If, in fact, we omit the problem being driven by noble motivations, we dramatically reduce camp reality, we reduce and adjust it to our a priori assumptions. One does not need to read too much into camp texts to find confirmations of the importance of play, and laughter, which accompanied the cruellest of experiences. A confirmation of that is offered by Borowski's already quoted words: "we play like we can. As if you could endure otherwise." The characters of Pankowski's Teatrowanie nad świętym barszczem boast in a similar manner: "Oh, we played... "cause... the times were grim..." 35 . Essentially agreeing with the noble conviction of Marta Piwińska, the authors of Oświęcim nieznany, published in 1981, actually decided to include in it a chapter entitled "Śmiech w piekle" [Laughter In Hell]. Fortunately they were not hampered by a fear of offending "the internees" suffering and martyrdom", or of any possible accusation of undermining the "gravity of the entire issue of the extermination". ${ }^{36}$ They came to the conclusion that "the already distant perspective allows one to carefully examine the sensitive, it would seem, issue of laughter, comicality, jokes in the inferno of a Nazi camp" ${ }^{37}$ That was proved by questionnaires filled out by former internees (including one of the authors); they confirmed the importance of laughter in camp life. The authors of

\footnotetext{
${ }^{34}$ Any unequivocal diagnosis is hampered by the exceptional story of the 1999 Camp Comedy by the English playwright Roy Kift, which premièred on stage a whole 13 years after being published, and was staged at a theatre in Legnica. In it, he reconstructed the fortunes of the Karuzela cabaret, which operated in the ghetto of the Czech Terezin (Theresienstadt). After several unsuccessful staging attempts, Kift became convicted that in his lifetime "the play will not be staged in a professional theatre". After the première, he stressed his satisfaction and joy in being able to see it in the Legnica theatre. He praised the courage emphasising the fact that the project was neither fulfilled in Germany, where he lived, nor in England, where he was born, nor in France, where supposedly there was not enough money for the planned première; vide http://gazeta.teatr.legnica.pl/index.php/akt-artykuly/4463-komedia-obozowa-szalona-groteska-w-cieniu-zaglady [accessed on 9 January 2014].

${ }^{35}$ M. Pankowski, "Teatrowanie nad świętym barszczem”, in: ibid., Teatrowanie nad świętym barszczem. Wybór utworów dramatycznych, afterword K. Latawiec, Wydawnictwo Literackie, Krakow 1995, p. 108.

${ }^{36}$ Z. Jagoda, S. Kłodziński, J. Masłowski, Oświęcim nieznany, foreword J. Bogusz, Wydawnictwo Literackie, Krakow 1981, p. 135.

${ }^{37}$ Ibid., p. 138.
} 
Oświęcim nieznany defined it, though, many years later as laughter which was "bitter, macabre, grim, crematorial, but they also unequivocally indicated its specific aesthetic category: vulgar, coarse, cheap". ${ }^{38}$ Herminia Naglerowa defined the humour in Soviet prisons completely differently, distancing herself from the "grimness" she called it mildly as being "rather student-like, collective". ${ }^{39}$

The importance of laughter was emphasised in virtually all theories of the grotesque. Even Wolfgang Kayser stressed its role in a situation "which does not actually offer any other possibility of releasing tension", laughter which "sounds more terrible than the worst curses". ${ }^{40}$ For Bakhtin, the liberating reviving laughter resulting from the carnival perception of the world constitutes the true nature of the grotesque. For the Russian researcher, the latter was a "laughing freedom". ${ }^{41}$ Jennings found in the grotesque a "neutralising mechanism", yet he warned against classifying it conveniently as the scene of a grotesque situation

in which next to atrocity or tragedy there appears comicality [...] Both aspects must be directly and definitively, with complete certainty included in the scene itself, visible without any reflective intervention, they must be a result of a serious distortion of the elements of an organised reality. ${ }^{42}$

\section{$* * *$}

In the introduction to her memoir Po wyzwoleniu... (1944-1956), Barbara Skarga reminisced that gulag was a "world of colossal absurd", ${ }^{43}$ while Anatol Krakowiecki referred to it as a world of "exceptions without any rules". ${ }^{44}$ For Wittlin, Soviet Russia was a "world of the greatest paradoxes", ${ }^{45}$ a "world of the greatest freedom of citizens", where "imprisonment or sending a person to hard labour in Siberia or execution by firing squad requires the complete and voluntary consent of the accused". ${ }^{46}$ Grubiński, then, noted that the USSR was a country where "the owners of Rolls-Royces are ill-shod". ${ }^{47}$ Leo Lipski in a story Dzień $i$ noc argued that the Soviet Union was a Kafkaesque world, "a made-up world". ${ }^{48}$ A bit later,

${ }^{38}$ Ibid., p. 142.

${ }^{39}$ H. Naglerowa, "Humor nie w porę", in: ibid., Kazachstańskie noce, Katolicki Ośrodek Wydawniczy „Veritas”, London 1958, p. 175.

${ }^{40}$ W. Kayser, op. cit., p. 27.

${ }^{41}$ M. Bakhtin, op. cit., p. 94.

${ }^{42}$ L. B. Jennings, op. cit., p. 62.

${ }^{43}$ B. Skarga, Po wyzwoleniu...(1945-1956), Wydawnictwo „W drodze”, Poznań 1990, p. 5.

${ }^{44}$ A. Krakowiecki, Książka o Kotymie, Katolicki Ośrodek Wydawniczy „Veritas”, London 1950, p. 201.

${ }^{45}$ T. Wittlin, Diabet w raju, Wydawnictwo „Polonia”, Warsaw 1990, p. 233.

${ }^{46}$ Ibid., p. 50.

${ }^{47}$ W. Grubiński, Między młotem a sierpem, Wydawnictwo „Czytelnik”, Warsaw 1990, p. 186.

${ }^{48}$ L. Lipski, Dzień i noc. Na otwarcie kanatu Wotga-Don, Wydawnictwo UMCS, Lublin 1998 , p. 33 . 
he added, and concretised, in Piotrus that in Russia he learnt what "true turpitude" was ${ }^{49}$ How, then, one should recreate that world to shape it, to bring the reader closer to understanding the communist "super-reality", to use the excellent term of Alain Besançon from Court traité de soviétologie à l'usage des autorités civiles, militaires et religieuses..$^{50}$ Skarga mentioned that gulag internees "promised themselves to describe it with humour". She stressed the significance of mockery in the description of the gulag world because "it sees everything more sharply, and it depicts it in more detail". ${ }^{11}$ In laughter, she accentuated "the victory of the vanquished." In the same vein, prison pre-gulag life was described by Herminia Naglerowa, who emphasised that humour constituted the only form of "maintaining the fullness [...] of the spiritual being" of the internee, that it was "the only form of the struggle". ${ }^{52}$ Yet such a perspective, as indicated by the author of Po wyzwoleniu... herself, was missing from her book: "Today, it is much harder for me to retain that disposition, maybe because I am looking from a distance, because I am no longer the actor but a spectator aware of the moral and physical havoc wreaked by those years". ${ }^{53}$ Another role and another perspective? Different knowledge and a different cognitive horizon? Skarga appears to have submitted to the conviction that havoc requires a language other than the language of humour or satire or even the grotesque, thus joining the main stream of Polish Gulag literature devised, with slight modifications, by Naglerowa, Beata Obertyńska, and Gustaw Herling-Grudziński. That does not mean, however, that those works lacked grotesque situations combining terrifying and comical aspects, subjected to the laws of the absurd, ${ }^{54}$ an over-abundance of which was offered by camp reality. The author of Kazachstańskie noce strongly underlined the significance of the transformation into joke of the atrocity of prison/camp reality, which enabled "short careless moments" 55 of spiritual detachment. Yet only some individual records of those moments can p. 132.

${ }^{49}$ L. Lipski, "Piotruś", in: ibid., Piotruś, Oficyna Druków Niskonakładowych, Olsztyn 1995,

${ }^{50}$ A. Besançon, Krótki traktat sowietologiczny na użytek władz cywilnych, wojskowych i religijnych, Wydawnictwo KOS, Krakow 1980, p. 29.

${ }^{51}$ B. Skarga, op. cit., p. 6.

${ }^{52}$ H. Naglerowa, Humor nie w pore, op. cit., p. 175. The remarks of the Polish writers were close to a thesis by A. Stern (Philosophie du rire et des pleurs, Presses Universitaires de France, Paris 1949, as quoted in: Z. Jagoda, S. Kłodziński, J. Masłowski, op. cit., p. 149), who argued "that laughter is a reaction to downgrading values, that it is as if a negative value judgement, regarding a downgrading of values", that laughter "was an expression of the sense of satisfaction in a spiritual victory over that which defies the principles of man".

${ }^{53}$ B. Skarga, op. cit., p. 5. M. Czermińska (Autobiograficzny trójkąt. Świadectwo, wyznanie $i$ wyzwanie, Wydawnictwo Universitas, Kraków 2000, s. 173) wrote that "Skarga presented not only the terror of the Soviet «prison civilisation», but also wrote that it was ruled by the absurd, which sometimes evoked a reaction of laughter in the wretched victims. That laughter was extremely important for maintaining one's internal freedom".

${ }^{54}$ L.B. Jennings, op. cit., p. 58.

${ }^{55}$ H. Naglerowa, Humor nie w pore, op. cit., p. 175. 
be found in the texts of the quoted authors. A grotesque nature is sometimes suggested by the titles of the works. One of Naglerowa's stories was entitled, without the expected creative consequences, Chaplin $w$ tagrze [Chaplin in the gulag]. The author of Ludzie sponiewierani achieved grotesque effects rather incidentally, against her creative intention. They resulted from her excessive care for the beauty of the language, and the poetics of expression redundant in the creation of the space of death. ${ }^{56}$ Much more coherent with the contents seem the grotesque titles of the chapters of Ksiażka o Kolymie by Krakowiecki: "Szwejk na Kołymie" [Švejk in Kolyma], "Et nihil humani"... The latter of the fragments referenced above is particularly significant; in it the author, revising the beautiful humanistic tradition in the description of the horrible and absolutely dehumanised reality of Kolyma, recalled his various camp tasks. Krakowiecki was openly proud stating that "he chopped no shit with a pick" preceding that noble declaration with a Terence maxim "Homo sum, et nihil humani". ${ }^{57}$

One should note, though, that the title "announcements" of the grotesque were not maintained throughout Naglerowa's or Krakowiecki's texts. The situation was different in the works of Grubiński and Wittlin, who framed the world of Soviet captivity holistically in a satirical manner, ${ }^{58}$ usually in the form of "laughter through tears". Unlike in the stories by Leo Lipski or Paweł Mayewski, who while emulating their masters, i.e. Louis-Ferdinand Céline and Franz Kafka, consistently created a space which evoked terror, and did not invite even a glimmer of light into the space of the gulag all-darkness.

Those individual records in the works by Herling, Naglerowa or Krakowiecki do not seem a result of implementing the principle of humorous reflection of gulag reality. Quite the opposite: they rather indicate a persistent striving for mimesis, recreating the "true" image of the world, something that the "Polish witnesses of GULag" ${ }^{59}$ cared about the most. And in that world, the binding principle was: "both funny and terrifying" ${ }^{60}$ to use an excellent Russian saying, almost perfectly aligned with the fundamental idea of the grotesque as any attempt at understanding the world "of exceptions without any rules" forced people almost by default to

${ }^{56}$ H. Naglerowa often referred to mythology: in a story entitled "Ręce i ziarna" (in: Ludzie sponiewierani, op. cit., p. 88) the narrator mentioned the rinsing of hands "in the pink glimmer of dawn", which was accompanied by a thought "after Homer on rosy-fingered dawn - Eos Rhododactylos".

${ }^{57}$ A. Krakowiecki, op. cit., p. 137.

${ }^{58}$ For W. Kayser (op. cit., p. 27) one of the types of the grotesque was the grotesque "stemming from the satirical view of the world".

${ }^{59}$ A term by I. Sariusz-Skąpska, Polscy świadkowie GUŁagu. Literatura łagrowa 1939-1989, Krakow 1995.

${ }^{60}$ L. B. Jennings (op. cit., p. 46) strongly underlined that "the grotesque creature was usually a demonic or foolish character; thus we can say that it included a combination of terrify ing and comical features - or more precisely: that it evoked in readers fear and amusement simultaneously" [space - T. S.]. 
enter a "terrifying and comical" space. Polish writers not only insightfully grasped the "phenomena" of the grotesque nature of the Soviet/Gulag world, but also tried to define it expressis verbis. Krakowiecki referred directly to the digestive problems of the starved internees caused by slightly bigger food rations at the transfer prison as "Vladivostok grotesque: people get sick of... overeating". ${ }^{61}$

Yet the space of the grotesque opened the widest within the process of learning about the stories of co-Gulagers. Polish witnesses faced events which were not even imaginable. One such story, and it was one of many, typical for "biographic micro short stories" ${ }^{\prime 2}$ of the Polish Gulag prose, can be found in Ksiażka $o$ Kotymie. Krakowiecki told the story of an old Bolshevik arrested during the Great Purge, who through being beaten every night, held in detention, and being threatened was forced to plead guilty to fabricated accusations. He stood up to it very long despite severe torture. Eventually, not only did he plead guilty, but he also created an action-espionage story:

I testified that I exchanged letters with Hitler [...], that I appealed to Hitler to seize Baku immediately [...] But that was not enough for me, so I willingly added that I also wrote to Puyi, the emperor of Manchuria to seize Tiflis. That caused a shock. I received a whole pile of cigarettes, I received a proper meal and I was escorted [...] to the infirmary. ${ }^{63}$

Sometimes, though probably not in such an "attractive" form, that applied to Polish authors as well. In A World Apart, Herling recalled the "first hypothesis" of the accusation leveraged against him. It was based on the sound similarity (in Russian) between his surname and the surname of a Luftwaffe marshal, and the high boots in which he was caught on the border. That enabled the Soviet slyedovatyels to develop the judgement: "Polish officer in the pay of the enemy". ${ }^{64}$ Then, the surname of the author of Ksiazka o Kolymie was connected by them with the name of the former capital of our country, and thus led them to the conclusion that Krakowiecki was "nawierno samyj gławnyj pomieszczyk Krakowa". ${ }^{65}$ And based only on that, the Polish journalist could not avoid the sentence. So it is no surprise that one Bronsztejn was sent to a Gulag because his surname sounded identically to Leon Trotsky's true familia.

Works which reconstructed Gulag reality include many images closely related to the primary meaning of the term the grotesque. There appear characters of damaged, deformed, beast-like monsters. Herling-Grudziński used the grotesque both for depicting groups ("we looked like the legs of some enormous black

${ }^{61}$ A. Krakowiecki, op. cit., p. 83.

${ }^{62}$ A term by W. Bolecki, Inny świat Gustawa Herlinga-Grudzińskiego, WSiP, Warsaw 1994, p. 99.

${ }^{63}$ A. Krakowiecki, op. cit., p. 165.

${ }^{64}$ G. Herling-Grudziński, ,,Inny świat”. Zapiski sowieckie, Czytelnik, Warsaw 1998, p. 16. [English version: Herling-Grudziński, G. A World Apart. London 1986]

${ }^{65}$ A. Krakowiecki, op. cit., p. 50. 
caterpillar, whose head, pierced in the zone by the four blades of the searchlights, bared the teeth of gleaming barrack windows at the sky"), ${ }^{66}$ and, more often, in creating animalistic individual portraits. There Stalin "the murderer" "looked like a huge sewer rat covered with slime, caught suddenly in a beam of light" ${ }^{67}$ The same, pejorative, it would seem, the term "sewer rat" was used by Herling for an inmate he befriended, who returned "stinking" 68 from the sanitation brigade. Yet the words surely cannot be blamed for offering negative ethical evaluations. The author of $A$ World Apart dehumanised externally, but he cared for internal humanity. He compensated the external mutilation or disfiguration with spiritual dignity. And that seems an important characteristic of Polish Gulag literature, in which amusement and contempt voluntarily evoked with the sight of a crippled or deformed person ${ }^{69}$ is usually substituted with sympathy. Usually, though not always. In $A$ World Apart, one can find the shocking description of an inmate suffering from night-blindness, who is terrifying and amusing at the same time:

he searched for the gangway with his outstretched foot. When his leg found it, he walked halfway across in a few long steps and suddenly stopped. Then he raised his right leg into the air and waved it several times in mid-air like a ballerina, but every time it landed again in empty space - the plank was very narrow - and he put it down again and froze in expectation. It was all obscurely funny and did not arouse our sympathy. Only later we understood that we had been watching a grotesque dance of death. ${ }^{70}$

A similar reaction was evoked by a gulager from the morgue, which clearly indicates that Herling "did not spare" the inmates, who "proclaimed «the end of all this suffering», with his own Second Coming - «I am Christ in the rags of a prisoner»". The inmates reacted to that statement with loud laughter, which subsided when the "imposing, tall, almost splendid" "Christ" jumped into the fire. ${ }^{71}$

A perfect example of a grotesque beast-like monster was the title character of Naglerowa's story, Dunia, who "was as if a peculiar creature with the features of various animals", with lips (?) turned into a "mouth with wolf's, tiger's or gorilla's teeth". ${ }^{72}$ In that text, there actually occurs a fundamental reversal of the situation: the terror at the sight of the "monster" is accompanied by laughter as the monster

${ }^{66}$ G. Herling-Grudziński, op. cit., p. 75. The description of bathing inmates is also both naturalist and grotesque: "Thin shadowy forms, with drooping testicles and fallen stomachs and chests, their legs covered with open sores and joined like two matchsticks to thin hips, bent under the weight of the pails, puffing from exhaustion in the steamy atmosphere of the hut." (op. cit., p. 209)

${ }^{67}$ Ibid., p. 75.

${ }^{68}$ Ibid., p. 214.

${ }^{69}$ Cf. L. B. Jennings, op. cit., pp. 48-49.

${ }^{70}$ G. Herling-Grudziński, op. cit., p. 87.

${ }^{71}$ Ibid., p. 338.

${ }^{72}$ H. Naglerowa, "Dunia", in: ibid., Ludzie sponiewierani, Biblioteka Orła Białego, Rome 1945 , p. 46. 
is croaking. It is laughing at itself, but it is also laughing at the terror it evokes. Naglerowa, according to the indicated tendency of the Polish Gulag prose, revealed the human heart of that "monstrosity" showing her love for a child, and hatred towards the tormentors. One can also find some naturalistic-grotesque descriptions of internees in the book by Obertyńska, who was not very prone to sympathy, rather professing the principle of "moral naturalism". ${ }^{73}$ In Krakowiecki's book, one of the most striking description is that of a brigade exiting the zone for work, which was accompanied by the gulag orchestra:

\begin{abstract}
"Workers" are leaving for labour. A full set: the first, the second, the third - jailers - dogs. They are sent off by an orchestra! Near the gate, a dozen or so ragamuffins, holding musical instruments, start playing. It's no cooler than minus 35 degrees, but that should be enough, right? Can anyone play in such bitterness? ${ }^{74}$
\end{abstract}

Borowski saw the same thing in Auschwitz, which should not be surprising when one realises the basic analogies between both "camp civilisations" ${ }^{75}$ In fact, an identical, almost "idyllic image" was included by Leo Lipski in the story entitled Dzień i noc.

The mocking yet grotesque intentions of Grubiński and Wittlin, focussed on malice and snide derision, ${ }^{76}$ are revealed in the titles of their works. Their fundamental difference is striking. Wittlin and Grubiński countered "serious" titles, i.e. A World Apart, $W$ domu niewoli, Na nieludzkiej ziemi, which mainly stressed the dehumanised nature of the described reality, with not-so-much "straight up" titles: Diabet w raju, Między mtotem a sierpem. The title of Wittlin's book, which consisted of cunningly arranged satirical stories, some humorous tales or burlesques, perfectly fulfilled the principle not so much of harmonising as actually of a co-existence of dissonances. A similar principle was used by the author in the titles of the chapters, which also work perfectly as separate entities. Wittlin, the creator

${ }^{73}$ H. Siewierski, Spotkanie narodów, Instytut Literacki, Paris 1984, p. 19.

${ }^{74}$ Krakowiecki, op. cit., p. 138.

${ }^{75}$ A. Krakowiecki (op. cit., p. 248) offered a detailed specification: «Vernichtungslager Auschwitz» - Oświęcim and «Uprawlenie Siewiero-Wostocznych Isprawitielno-Trudowych Łagierej»-Kolyma.

«Lasciate ogni speranza!»

«Lager» and «Gulag». Barbed wire! Degenerated ruffians: «kapo» and «staroste», «Sonderkomando» and «specizolator».

Both here and there «Strafkomando» and «sztrafkomandirówka» - the name's the same. The same essential matter... «Muselmanns» in Oświęcim and «dochodiags» in Kolyma.

They multiply, they multiply lists, summaries, and analogies".

${ }^{76}$ L. B. Jennings, op. cit., p. 68. 
of political farces and comedy sketches before WWII, used almost the entire array of situation and word comicality devices, drawing from pure nonsense, and sometimes verging on grotesque situations. He achieved mastery in his dialogues. It is worth quoting the punchline of the chapter-story entitled Samoloty Napoleona, in which a furious guard being mocked mercilessly by prisoners he was escorting imprudently falls into a carefully set trap when trying to defend the greatness of the Soviet army. He admitted that all the planes were French, "the same which [...] Napoleon left near Moscow". The writer did not stop there, though it could had been a sufficient punchline amplifying the grotesque nature of the situation. At the outburst of wild laughter of the prisoners, "in the guard's eyes there appeared two heavy tears, and the big and powerful man started to cry like a baby". ${ }^{77}$

Grubiński wrote in a similar manner. In the title of the memoir Między młotem a sierpem, referring to the colloquial idiom [between the hammer and the anvil, (English equivalent: between a rock and a hard place)], but maybe also to the famous chastushka, ${ }^{78}$ somewhat ironically, the author slightly comically stressed the absolute hopelessness of his situation by substituting the original anvil with a sickle. But also because he was probably the most afflicted by the absurdity of Soviet jurisdiction. Grubiński was sentenced to death for a play entitled $\mathrm{Le}$ nin, which he had written twenty years earlier in independent Poland, in which, according to the conclusion of the judgement, "he smeared the greatest mind of humanity". ${ }^{79}$ And there would be nothing strange in that had the Soviet "jurisprudence" not tried to find a legal justification for the intention to eliminate an ideological enemy. In fact, Grubiński's case was subject to an article which stated that "any person who attempts to propagate anti-communist opinions shall be liable to court proceedings regardless of their country of citizenship when the person enters the jurisdiction of a Soviet tribunal" ${ }^{80}$ In his book, the writer reconstructed the arrest, the investigation, the so-called court proceedings with the death penalty, almost one hundred days of incarceration awaiting an execution by a firing squad, and finally a review of the judgement, and his internment in a gulag. He presented those extremely dramatic experiences in an almost cheerful narrative, with slight irony, which he used to view both himself and his oppressors. Thus, one of the major Polish comedy writers of the first decades of the $20^{\text {th }} \mathrm{c}$. delivered his prison

${ }^{77}$ T. Wittlin, op. cit., p. 127.

${ }^{78} \mathrm{~W}$. Bukowski (I powraca wiatr..., trans. from Russian A. Mandalian, poems trans. by S. Barańczak, prepared for printing by J. Juryś, Res Publica, Warsaw 1990, p. 89) quoted a song extremely popular among factory workers: "Raise the hammer, lower the sickle -/ That is our Soviet emblem./ Cut if you want to, beat if you need to,/ Either way the prize is a dick." Vide also: T. Klimowicz (Przewodnik po wspótczesnej literaturze rosyjskiej i okolicach (1917-1996), Towarzystwo Przyjaciół Polonistyki Wrocławskiej, Wrocław 1996, p. 51) quoted the original version: "Swerchu mołot, snizu sierp -/ eto nasz sowietskij gierb. Choczesz - żni, a choczesz kuj,/ Wsie rawno połuczisz chuj".

${ }^{79}$ W. Grubiński, op. cit., p. 84.

${ }^{80}$ Ibid., p. 85. 
and gulag life in the form of a grotesque drama, a tragicomedy even, which could receive the title: Śmierć za napisanie sztuki ${ }^{81}$ [Death For Writing A Play]. By declaring himself to be a European rationalist, he accurately noticed all the absurd, not just in Soviet but also Russian life. An excellent example of that would be the reconstruction of the attempt to read a terribly dirty sign in the prison corridor. Upon a long struggle, on a bright sunny day the narrator was finally able to decipher the words: "«Sabliudajtie czistatu» - «Stay clean»". From the very start, Grubiński was a proponent of an anti-martyrdom attitude as he "did not enjoy the martyr's attitude", especially "while crouching somewhere", ${ }^{82}$ he did not shy away from frivolity, and he even sometimes used the genre of a pamphlet. He masterfully created dialogues, thus proving to be a highly-skilled playwright. His book, when compared to other Gulag texts, seems almost saturated with those. One of the superb instances of those was the record of an exchange at the prison library, in which when asked about the greatest Russian classics like Dostoevsky, Blok, Turgenev, and Goncharov, the librarian asked him each time to repeat the name unknown to her, only to state: "no, we don't have him". A similar answer was offered to the request for Pushkin's or Lermontov's poems. She recalled Tolstoy only as the author of Peter $I .{ }^{83}$ Grubiński did not stop with that, and released his malicious satisfaction by creating an almost grotesque vision of the "flourishing readership" in the Soviet Union, which was proved by the grand figures of books being published in a country where illiteracy had been systemically eradicated. The trick was to "tear out a piece of paper from the cover of And Quiet Flows the Don, you roll it up into a cigarette, then a second and a third one, and thus the Don is ablaze". The same applied to the readership of other classics, not excluding the major ones: "The whole of Russia devours Capital by Marx, and blows it through the nose; in that sense all Soviet citizens are heavy Marxists" ${ }^{84}$ However, Grubiński achieved the fullest, masterful "harmonisation of dissonances" in the superb description of the "free Soviet citizen", whom he defined as "deceived liar, a robbed thief, and a denounced snitch". 85

In the visions of Soviet Russia offered by Wittlin and Grubiński, in their images of Gulag reality, one could surely find some elements of carnivalisation, yet they are dominated by a tendency to monstering and hyperbolisation. At its foundation there lies both a sense of the absurdity of that world, and a disagreement for the reality as the grotesque, as aptly noted by Elżbieta Sidoruk, "enters into a play with the absurd, and thus tries to subdue it". ${ }^{86}$

\footnotetext{
${ }^{81}$ Ibid., p. 105.

${ }^{82}$ Ibid., p. 51.

${ }^{83}$ Ibid., p. 65-66.

${ }^{84}$ Ibid., p. 67.

${ }^{85}$ Ibid., p. 168.

${ }^{86}$ E. Sidoruk, Groteska w poezji Dwudziestolecia. Leśmian - Tuwim - Gałczyński, Wydawnictwo Uniwersytetu w Białymstoku, Białystok 2004, p. 14.
} 
Yet neither Wittlin nor Grubiński could receive the victor's palm in the satirical description of the Soviet camp civilisation. It was borne proudly and justly by Witold Olszewski (Stanisław Kempiński) being the author of a novel entitled Budujemy kanat. Wspomnienia kierownika biura planowania published in 1946. In it, he developed a grotesque vision of the Stalinist world as a whole. In the handful of reviews of the forgotten book ${ }^{87}$, which Józef Czapski recommended as a book on Russia to be immediately translated "into all the languages of the world", the reviewers tried to define it as a parody or a humoresque, and as a "belligerent mockery of a social nature". Czapski himself defined the novel as a "wild, scandalising, grimly comical book", while its sense of humour should be considered in quotation marks, which for people who do not know Soviet Russia will seem a "random surrealist fantasy" ${ }^{88}$ Thus the writer characterised it in a way which unequivocally classified the book as a grotesque work. In the foreword to his novel, Olszewski presented its origins, which are particularly noteworthy. The idea emerged in the January of 1943 from a reflection of two Poles on the Suez Canal who had been released from a Soviet Gulag eighteen months earlier. In fact, the camp experiences of the ex-Gulagers from various "construction sites of socialism", and the knowledge gathered there on the White Sea Canal led them to the question of how the Soviets would have built such a canal. The novel, written over a three year period from January 1943 to 1946, was actually an artistic answer to the strictly "engineering" issue. In it, Olszewski transformed and hyperbolised the world he knew perfectly, a reality which he had known since his childhood. Maybe because of that as well, unlike in the case of other Polish authors, he could refer to that world with such an artistic distance, and he could subject it to grotesque "processing".

Olszewski was a nom de plume of Stanisław Kempiński, born and raised in Russia, who upon publishing his masterpiece of Gulag literature went silent, and relocated to South America. From the introduction to the novel, one learns that the author used in it his personal memories, experiences, and observations, both from his time spent in the so-called Soviet freedom, and in numerous prisons and camps while building the northern railway route: in Kotlas, Aykino, and Mieżogu. Olszewski's own experiences (his leaving Stalin's empire with Anders's army, his stay in the Middle East) enabled him to considerably expand the space of the story of the novel, and to cross the borders of Stalin's empire. Yet that phrase is incorrect, as in the hyperbolising vision offered by the author, the entire world is

${ }^{87}$ The novel's reception did not change much with its domestic edition of 2014.

${ }^{88}$ J. Czapski ("Rodzynki w elewatorach”, in: ibid., Rozproszone. Teksty z lat 1925-1988, collected by and with commentary of P. Kądziela, Biblioteka „Więzi”, Warsaw 2005 p. 141) stressed that Olszewski's novel "helps one realise [...], unlike any other study, to what extent the hierarchy of values had been distorted and reversed in the Soviet Union". Polish emigration literature added one more novel which could be considered as a quasi-grotesque book: Republika atomowa by Zygmunt Bohusz-Szyszko. 
a "Universal Soviet Union", ${ }^{89}$ consisting both "old-Soviet" union republics, and the new ones, included in the "soyuz" upon the victory in the Great Patriotic War, from around the world (some time later Zygmunt Bohusz-Szyszko used a similar idea in Atomowa pożoga). So there are the Australian and the Eskimo SSRs, there are the Canadian and the South American SSRs, and the opening of the canal even gathered comrades from the South African Bush Republic, though "somewhat too hairy", which evoked the narrator's doubts whether those "were not, actually, gorillas" ${ }^{90}$ That question clearly discredits the "inter-nationalistic" upbringing methods of the communists. Within the "universal soyuz" there are now living kolkhozniks from Tahiti, merited milkmaids from the Netherlands, and the extreme professionals from the Punjab delivering on a regular basis over 200 per cent of the norm of ebony guard towers. The entry to the NKVD HQ is decorated with human skulls on pales "sent by Māori komsomolets from the New Zealand ASSR. Somewhat as an invitation to a Socialist Competition in bone haberdashery for komsomolet comrades who live slightly to the north of them". ${ }^{91}$

However, before Olszewski led his protagonist with a telling (and related to the drama traditions of Alexander Griboyedov) name of Bezgołosow [Voicelessov] to the Jewish ASSR to the construction of the Sovcanal linking the Medisoviet Sea (called the Mediterranean in the "prehistoric" times) with the Red Sea, before they visit Tel-Stalin (formerly known as Haifa), he presents extremely suggestively the "Land of All Joys". That is possible thanks to the perfectly planned story of the novel, which excellently combined realistic elements, almost resembling a physiological layout, with an anti-utopian "surrealist fantasy". It received an exceptional compositional framing: the story begins with a resolution of the Highest Council and the National Council on the start of the construction of the Soviet Canal, while it concludes with a grand celebration of the opening of the Sovcanal, the linking of both seas, which was expected to feature an appearance of Ilyich extracted from the mausoleum. In the Red Sea, surprisingly, the water retained its normal colour, but, something the constructors, having been subjected to the successful process of the perekovka of souls, believed strongly, "it will soften a bit - [and] it will have to [...] change its colour". ${ }^{2}$ As a result of the resolution, it was necessary to gather "for starters" "between two to three million workers" 93 to the northern gulags, who first had to deliver material for the construction of the Sovcanal, as the stones from the taken down pyramids would not suffice.

That composition, in fact, enabled Olszewski to recreate the entire Soviet reality covering firstly a few hours of life in the so-called freedom, i.e. in the

${ }^{89}$ W. Olszewski, Budujemy kanat. Wspomnienia kierownika Biura Planowania, Polski Dom Wydawniczy, Rome 1947, p. 130.

${ }^{90}$ Ibid., p. 182.

${ }^{91}$ Ibid., p. 20.

${ }^{92}$ Ibid., p. 60.

${ }^{93}$ Ibid., p. 14. 
"grand zone", then an incarceration, and, finally, the cruel everyday life in the northern camps. It also offered the writer a chance to reconstruct in an excellent realistic abridgement the process of creating that country upon the victory of the Bolsheviks. I.e. collectivisation, the Great Hunger, accelerated industrialisation, widespread corruption, the everyday life from before the Patriotic War subjected to brutal Sovietisation. The novel, as the author himself posited in the foreword, first written in "Russian, or more precisely Soviet" ${ }^{94}$ has lost much in its Polish version, yet even at the first encounter, what strikes one most is Olszewski's outstanding linguistic inventiveness. Inventiveness which in reality means ingenious imitation of the Soviet newspeak. The language of the novel is a peculiar mix of skaz, in its Soviet version, reflecting the mind and the language of an inhabitant of the "Land of All Joys", ${ }^{95}$ newspeak and polit-gramota gibberish, acronyms and neologisms ("gławbuch mięsokombinatu", "pomdyrektor", "admtech personel", "gławjużmorput", "narkomzdraw"), and the so-called ornamental prose (used by Andrei Pratonov and Boris Pilnyak), ${ }^{96}$ proved by various "someone else's words", fragments of speeches, and snippets emulating newspaper articles. All that is accompanied by humour which is absurd, but also terrifying and dark, offering a horrible reflection of everyday existence during the Great Hunger, to which the country crawled "in the glare of the light of the revolution". Its punchline is a remark about meat: "Fresh human is better than stinking feline". ${ }^{97}$ From the story of a biesprizornyj we learn that "in a hungry year - the uncle butchered [mummy], and made her into dumpling stuffing". ${ }^{98}$ Upon eating them, the boy suffered from stomach pain, so being convinced that the food was of "inappropriate quality", he went to GPU, for which he was rewarded by being taken to an orphanage.

The telling titles of the chapters engaging in an intertextual play with the texts which shaped the Soviet collective awareness, and which became ingrained in it are also extremely significant. In a chapter entitled "Jak rozległy kraj mój jest" [How Expansive My Country Is], the narrator describes his route to the camp in the North. The title is a Polonised version of the lyrics of Shiroka strana moya rodnaya, where the chorus states: "Ya drugoy takoy strany ne znayu, Gdye tak vol'no dyshit chelovy$e k$ ". Olszewski used a similar device in a title "Jadę, jadę, jadę do niej" [I'm Going, Going, Going To Her], which tells the story of the journey to the Construction of the Sovcanal. The reader can associate those words with the Russian folk song Troyka mchista, troyka skachet, the chorus of which features the expression of happiness of meeting one's sweetheart: Jedu, jedu, jedu k niej, jedu k liubuszkie mojej. In Olszewski's novel, the Sovcanal replaced the sweetheart. He included in the text

\footnotetext{
${ }^{94}$ Ibid., p. 11.

${ }^{95}$ Ibid., p. 8.

${ }^{96}$ Vide Historia literatury rosyjskiej XX wieku, A. Drawicz (ed.), Wydawnictwo Naukowe PWN, Warsaw 1997, pp. 212-240.

${ }^{97}$ W. Olszewski, Budujemy kanat, op. cit., p. 70.

${ }^{98}$ Ibid., p. 64.
} 
various slogans from the Soviet polit-gramota, with the novel's opening chapter entitled "Wielkiemu Stalinowi - Ura!" [For the Great Stalin: Hoorah!] There are many vulgarisms, which are used, however, almost exclusively by blatnys and biesprizornyje, i.e. the relics of "the truest counter-revolution and fascism". Olszewski perfectly depicted the special flavour of Russian, actually not only its camp variety. A fourteen-year-old prisoner having missed the answer to the question who the newcomers are, shouts: "speak up, "cause you can hear sh...", something that was admired by a law-abiding prisoner, who was delighted by her "expertise", and the precision of "expressing thoughts and even the correct accent". ${ }^{99}$ Another superb dialogue occurs during the so-called sanobrabotka, i.e. bath hygiene procedure. There, the prison hairdresser gives an order to a prisoner: " $\mathrm{C}$ 'mon, lift your piping - we be shaving your balls". When it turns out, though, that the piping rose by itself during the shaving, being offended she uttered words as if during a party meeting:

this is no place to be making jokes, you can't scare me, and you won't stop me from reaching my norm, and yet some cultural norms need to be observed though you have been placed in a prison - you're dealing with a woman here, I'm collaborator of the NKVD, not some prostitute, there's no need to rear your pony. ${ }^{100}$

Eventually, in a soft voice, somewhat flirtatiously, she offers him a job at the baths. In the record of the dynamics of the changes in the behaviour of the woman, from a strict official through a principled NKVD officer to a potential lover, Olszewski perfectly captured the mimicry strategy used by the "old-Soviets", ${ }^{101}$ personified the fullest by Bezgołosow.

The protagonist and the narrator of Budujemy kanat does not so much think anew as he knows that he needs to, or even wants to think that way. Angrily, he comments on any deviation from the solely just convictions. Therefore, he is not a person completely "devoid of a spiritual interior", he is not a model exhibit of homo sovieticus. One would rather need to concede that he is torn between kitmān and loyalty to polit-gramota. Not always, then, is he capable of managing his instinctive return to the thinking of the "prehistoric" times, which leads him to being sentenced. He received a penalty of eight years in the camp for uttering the words: "African hippopotamus - two poods I eat, three poods I sh...!" There, he committed a crime of using pre-metric units. And that proves not only "conspiring with the rotten past" 102 and "rightist deviation", but also activity within a hostile anti-Soviet "counter-metric organisation" and "inhuman approach to an overseas animal". ${ }^{103}$ The sentence enables the protagonist to ascertain, though, that a hippopotamus is Soviet, too, as it produces $1500 \%$ of the norm.

\footnotetext{
${ }^{99}$ Ibid., p. 33.

${ }^{100}$ Ibid., p. 32.

${ }^{101}$ Ibid., p. 182.

102 Ibid., p. 24.

${ }^{103}$ Ibid., p. 58.
} 
Olszewski included an excellent depiction of the signs of "Soviet patriotism indistinguishable from Russian chauvinism", which in the Stalinist period "took on the form of official madness". ${ }^{104}$ They appear particularly in the grotesque vision of the Russian imperial continuum. According to the novel's narrator, "the Stalinist political line" was introduced by Peter I when he gave the order to "hack a window to the West". He was unable to fulfil that task due to the "fascist reaction of those times". His "Soviet" opus magnum was continued "in a healthy manner" by Catherine II, as well as the great marshals like Suvorov, Kutuzov, and... Alexander Nevsky, whose grand intentions to unite "the whole World into One Union of Soviet Republics" was prevented by the lack of any "Lenin-Stalin Experience". ${ }^{105}$

The acuteness of the creation (reconstruction) of the instances of the absurd in the Soviet super-reality in Olszewski's work is best visible when compared to Vladimir Voynovich's novel The Life and Extraordinary Adventures of Private Ivan Chonkin, in which the grotesque, as aptly noted by its researcher, was used for "the purposes of realism". ${ }^{106}$ In both texts, one could find many similar ideas, which stemmed from, not to discredit the inventiveness of both authors, the Soviet nonsensical pretentiousness and ideological aberrations. The Arabic camel in Olszewski's novel sabotaging labour norms, and sent "for training to the Old Union" ${ }^{107}$ could be matched to Voynovich's dead horse, which under its hoof pressed a sheet of paper with the words: "if I fall, please consider me a communist"; 108 those expected by Bezgołosow in the desert sands, fertilised by the "natural depletions of the workforce", "both pines, and moss, and even berries", as well as a "scrub birch"109 (the results of the creative works of the scientists Miczurin and Łysenko), correspond to the revolutionary ideas of Voynovich's geneticist, who tried to cultivate a plant which would be both a potato with bulbs underground, and a tomato with fruit up top, which he called "PTS" 110 (Path To Socialism). However, Olszewski's inventiveness did not predict what Voynovich presented in his novel, i.e. distilling moonshine from manure or even using cockroaches as beasts of burden.

${ }^{104}$ L. Kołakowski, Główne nurty marksizmu. Powstanie - rozwój - rozkład, vol. III, Instytut Literacki, Paris 1976, p. 151. [English version: Kołakowski, L. Main Currents of Marxism: The Founders - The Golden Age - The Breakdown. New York 2005]. The philosopher argued that "the so-called propaganda declared incessantly that all important technical inventions and discoveries had been made by Russians, and to mention foreigners in that context was to be guilty of cosmopolitanism and kowtowing to the West".

${ }^{105}$ W. Olszewski, op. cit., p. 140.

${ }^{106}$ A. Dudek, "Groteska jako próba realizmu. O książce Włodzimierza Wojnowicza”, in: Emigracja i tamizdat: szkice o współczesnej prozie rosyjskiej, A. Drawicz (ed.), Wydawnictwo „Universitas", Krakow 1993, p. 208.

${ }^{107}$ W. Olszewski, op. cit., p. 175.

${ }^{108} \mathrm{~W}$. Voynovich, Życie i niezwykte przygody żotnierza Iwana Czonkina, trans. W. Dłuski, Fabryka Bestsellerów, Warsaw 2012, p. 279. [English version translated from Polish]

${ }^{109}$ W. Olszewski, op. cit., p. 173.

${ }^{110}$ W. Voynovich, op. cit., p. 59. 
Both novels fluctuate between fantasy and reality. But in a situation where reality is subjected to ideological pressure, it becomes alogical and unreliable, when "life itself is a satire" 111 a writer who tries to model it does not need to ensure the probability of his works. Therefore, one finds it difficult to agree with the statement that "mimesis in the case of presenting communist super-reality must lead to grotesque depictions", ${ }^{112}$ incredibly hilarious, yet even more terrifying. One could argue, then, that Olszewski's novel is dominated by that paradoxical feature of grotesque nature, so keenly identified by Kayser, which is included not in the "fear of death" but in the "fear of living". 113

If Olszewski's vision, to a lesser extent Wittlin's or Grubiński's visions, resembled the grotesque in Bakhtin's understanding of the term, if one could treat it as an example of the "ludic need to toy with form", then the visions by Leo Lipski and Paweł Mayewski were extremely close to the grotesque in Kayser's understanding, of a world which is alien, terrifying, and apocalyptical, yet expressed calmly, in the form of an indifferent naturalistic description, using linguistic narration with shocking meanings of images. Józef Wittlin in the introduction to Rzeka extremely accurately noted that Mayewski, the "anatomist of the rock bottom", "subjects us without any protection [...] to terror. He presents every detail at the bottom with extraordinary clarity. We are terrified not by the essence or the issue of terror, but by its "naturalness»". ${ }^{114}$ The world presented in Mayewski's stories is a reality devoid of any "glimmer of hope", ${ }^{115}$ a space of total loneliness, helplessness, fear, absolute alienation, where the struggle for one's survival is the binding principle, "so that you don't get shoved off of the only path towards salvation". 116 The first person narrator of the story entitled Komary calmly states: "the only way out leads either way to death", "death had to be fed, and its needs to be satisfied." 117 It is dominated by "the stench of mould" "the stench of rot", and "the stench of corpses". ${ }^{118}$ In the title story, the formation of the space almost automatically brings to mind Kafka's The Castle. In his stories, Mayewski created a whole range of grotesque figures: a ruthless and cruel urka with a hilarious nickname Babooshka Lenin (Komary), a much more menacing and blood-thirsty, quite literally, gulag physician, who satisfied his insatiable hunger by eating human flesh,

${ }^{111}$ Vladimir Voynovich's words, as cited in: A. Dudek, op. cit., p. 240. A bit further on (ibid., p. 245), the researcher concluded that "grotesque effects in the work were a result of the realistic attitude of the narrator, whose intention was to present the truth".

${ }^{112}$ A. Dudek, op. cit., p. 241.

${ }^{113}$ W. Kayser, op. cit., pp. 24-25.

114 J. Wittlin, "Przedmowa", [in:] P. Mayewski, Rzeka, trans. from English J. Kempka, Oficyna Poetów i Malarzy, London 1960, p. 8, 9. [English version translated from Polish]

${ }^{115}$ P. Mayewski, Rzeka, trans. from English J. Kempka, Oficyna Poetów i Malarzy, London 1960, p. $19,9$.

${ }^{116}$ Ibid., p. 25.

${ }^{117}$ Ibid., p. 24.

${ }^{118}$ Ibid., p. 15, 19. 
which he had delivered to him by a prisoner whose job was to dig graves. On that he conditioned the provision of help to the sick. The results of the gulag cannibalism are summed up by the doctor with the words concluding the story: "look at the bones lying around [...] just look at them. Picked clean". ${ }^{119}$

The world depicted in Leo Lipski's works seems even more shocking. He stressed that "you can deform only that which exists. You can't deform that which is invented", ${ }^{120}$ and thus equipped he set off to seek a language to indicate those deformations and paradoxes, dissonances and instances of the absurd. He tried to deform the language, and he rejected the rules of syntax. He was completely unconcerned about them; he sometimes fell back on a principle resembling the futurist slogan of "words in the wild", on sharp frames, and enumerations. From among many such fragments, it would be worth quoting one which recorded the "dance" rebellion of Poles, who received neither shovels nor spades for digging:

They made a bonfire. [...] They jumped like baboons. A large bonfire. It's colder and colder. You would like to step into the fire. My tailor did that. First, he started dancing around the bonfire. And then stepped into it. And his clothes caught fire. He danced on. Burning. The power plant was unreal, drawn with a stick. He danced his fiery dance with the power plant in the background. [...] Then they poured water over him. Then he froze, like Lot's wife. He could not move. But there was fire. In a frozen shell, in the fire, like a saint. He strolled. And the entire brigade went into a craze, and around him. They danced a dance. Boom-boom, like Negroes. ${ }^{121}$

For Lipski, the satire which dominated Wittlin's and Grubiński's books was not enough. Lipski distanced himself from Olszewski's (sombre) "carnival". He sought in his stories his "changing image together with hallucinations from many years back". ${ }^{122}$ He viewed camp reality as if from the perspective of an outsider. His sense of its absurdity was accompanied rather by indifference than discord, though he sometimes was not able to refrain from a more poignant derision. Lipski provoked the reader with full intent. His prose, which readers " $\mathrm{m} \mathrm{u} \mathrm{s} \mathrm{t} \mathrm{see",} \mathrm{is}$ like "being slapped in the face". ${ }^{123}$ With such blows the readers of all the "Soviet" stories of the author are struck: Dzien i noc, Wadi, and to a somewhat lesser extent Powrót. Their invariably first person narrator cannot understand the world, but neither does he try to make sense of it. He reconstructs everyday life, he reconstructs new events somewhat mindlessly, though he discusses events which demand to be commented upon. That is particularly visible in the story Dzien inoc, composed of a sequence of shocking images, though, actually, painful blows would be a better designation. The first blow is the necessity to "examine" within fifteen minutes 76 "frailing" gulagers, with the associated realisation that the fact of exceeding the pre-established percentage of the released is treated as sabotage,

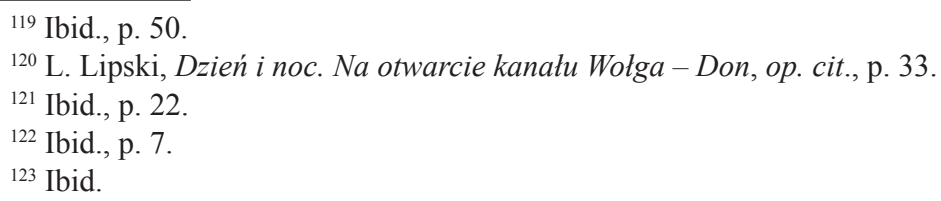


and entails another sentence. Second blow: pacifying the rebellion of a prisoner who refused to set off for work, and nailed his penis to the bunk. It is followed by more blows, amplifying the sense of an absolute inferno, framed with the image of the parade of a gaunt mob of tattered zeks at minus 40 degrees centigrade during the opening of the canal, which was accompanied by orchestra music. But in that world, which emphasised its grotesqueness even more, the narrator, between the marches accompanying the gulagers' parade, could also hear Felix Mendelssohn's Scherzo performed by Jakow Flier coming from the udarniks' barracks; he noticed the thighs and arms of the female inmates suddenly bringing to his mind the paintings by Edgar Degas and Auguste Renoir. What proved more important than desire was the need to regain one's "shaken balance".

Lipski offered a similarly dispassionate description of the world in Wadi, where "the condensation of death is incredible". Thus he depicted a monstrous vision of a mass of the bodies of people suffering from diarrhoea and typhus: "all had diarrhoea. Even the most beautiful girls. You discovered that whether you liked it or not in the latrine. Depending on their erotic talent, they wiped with pages from Lenin, stones, or nothing at all". ${ }^{124}$ The world in the story is a space of death and faeces, boiling in "tin chamberpots", a space of emotionless copulation - of people, and insects. Similar images of "stinking beings" in their dens covered in "urine and faeces crawling with flies" 125 were also offered, though rarely, by Naglerowa. Yet in Lipski's depiction, people are mere bodies which "gurgle, moan, wheeze, and snore", die, "release faeces", and meow like cats. They couple to forget women, there copulate "mad, lecherous, and insolent" flies "on the spoons, during meals, in the ears, and eye sockets". ${ }^{26}$ Even the moving image of the only instance of any feelings, when a loving woman tells fairy tales to her dying sweetheart, is brutalised by Lipski who highlighted the fact that the girl is being carefully fingered by a sick man lying next to her. Yet the process of recreation of that world hides, as Kayser would say, a mysterious liberating factor, an attempt to exorcise the demonic nature.

$* * *$

All Polish writers of Gulag literature were to some extent driven by the imperative of "the truth - the whole truth and nothing but the truth" ${ }^{127}$ They considered it their mission in relation to the free world. They actually subjected to that goal the poetics of the "photographic" realism of their prose. ${ }^{128}$ The fact that Gulag

${ }^{124}$ L. Lipski, "Wadi", in: ibid., Piotruś, op. cit., p. 43.

${ }^{125}$ H. Naglerowa, "Chaplin w łagrze", [in:] ibid., Ludzie sponiewierani, op. cit., p. 68.

${ }^{126}$ Ibid., p. 48.

${ }^{127}$ B. Obertyńska (M. Rudzka), W domu niewoli, Wydawnictwo „Pax” Warsaw 1991, p. 357.

${ }^{128}$ I discussed that in more detail in a study: "Formuły realizmu łagrowego", in: Marek Nowakowski i inni. Oblicza realizmu w prozie polskiej XX i XXI wieku, S. Buryła, J. Michalczeni and M. Urbanowski (eds.), IBL, Warsaw 2016, pp. 275-304. 
works include some satirical or grotesque elements in no way questions their objectivity or deprives them of their mission focus. On the contrary, in the attempts at creating/reconstructing the Stalinist ("Kafkaesque") world, the grotesque plays a special role as it helps amplify realism, indicating the effort in realistic copying of the world which was "both terrifying and comical." Their authors not so much were driven by the sense of the absurdity of that world, as they diagnosed and uncovered it. Thus the sources of grotesque nature ought to be identified both in the intent to offer a "proof" of the Soviet super-reality, and in the opposition towards that reality, and its rejection. Yet one should also emphasise the intention to inflict artistic revenge on the oppressors, who feared laughter the most, and who treated the absurd they created par excellence seriously.

Therefore, in conclusion, it is necessary to "correct" Borowski, and rather state: it is the truth, because it is the grotesque. But one could also, using Krakowiecki's words, express that thesis more poignantly: thanks to the grotesque, "the horror of slave labour of people driven to the rock bottom of human misery" proves much more intense, "the horror of the truth" ${ }^{129}$ speaks louder.

\section{Bibliography}

\section{Subject bibliography}

Grubiński Wacław, Między młotem a sierpem, Wydawnictwo „Czytelnik”, Warsaw 1990.

Herling-Grudziński Gustaw, Inny świat. Zapiski sowieckie, Czytelnik, Warsaw 1998.

Krakowiecki Anatol, Książka o Kotymie, Katolicki Ośrodek Wydawniczy „Veritas”, London 1950. Lipski Leo, Dzień i noc. Na otwarcie kanału Wotga-Don, Wydawnictwo UMCS, Lublin 1998.

Lipski Leo, Piotruś, Oficyna Druków Niskonakładowych, Olsztyn 1995.

Mayewski Paweł, Rzeka, trans. from English J. Kempka, Oficyna Poetów i Malarzy, London 1960. Naglerowa Herminia, Ludzie sponiewierani, Biblioteka Orła Białego, Rome 1945.

Naglerowa Herminia, Kazachstańskie noce, Katolicki Ośrodek Wydawniczy „Veritas”, London 1958. Olszewski Witold, Budujemy kanat. Wspomnienia kierownika Biura Planowania, Polski Dom Wydawniczy, Rome 1947.

Skarga Barbara, Po wyzwoleniu...(1945-1956), Wydawnictwo „W drodze”, Poznań 1990.

Voynovich Vladimir, Życie i niezwykłe przygody żotnierza Iwana Czonkina, trans. Wiktor Dłuski, Fabryka Bestsellerów, Warsaw 2012.

Wittlin Tadeusz, Diabet w raju, Wydawnictwo „Polonia”, Warsaw 1990.

\section{Object bibliography}

Bachtin Mikhail, Twórczość Franciszka Rabalais'go a kultura ludowa średniowiecza i renesansu, trans. Anna and Andrzej Goreń, Stanisław Balbus (ed.), Wydawnictwo Literackie, Krakow 1975.

Bolecki Włodzimierz, “Groteska, groteskowość”, in: Słownik literatury polskiej XX wieku, editorial team: Alina Brodzka, Mirosława Puchalska, Małgorzata Semczuk, Anna Sobolewska, Ewa Szary-Matywiecka, Zakład Narodowy im. Ossolińskich, Wrocław - Warsaw - Krakow 1992, pp. 345-361.

${ }^{129}$ A. Krakowiecki, op. cit., p. 184. 
Burska Lidia, “Obozowa literatura”, in: Stownik literatury polskiej XX wieku, editorial team: Alina Brodzka, Mirosława Puchalska, Małgorzata Semczuk, Anna Sobolewska, Ewa Szary-Matywiecka, Zakład Narodowy im. Ossolińskich, Wrocław - Warsaw - Krakow 1992, pp. 740-746. Dudek Andrzej, "Groteska jako próba realizmu. O książce Włodzimierza Wojnowicza”, in: Emigracja i tamizdat: szkice o wspótczesnej prozie rosyjskiej, Andrzej Drawicz (ed.), Wydawnictwo „Universitas”, Krakow 1993, pp. 225-248.

Groteska, Michał Głowiński (ed.), słowo/obraz terytoria, Gdańsk 2003.

\section{How to describe "the world of colossal absurd"? On the grotesque in Gulag literature}

(Summary)

The main aim of the paper is to reflect on the various forms of the disclosure and the use of the grotesque in the Polish camp literature. Prisoners, authors of books devoted to life in the camps, experienced life in conditions that we did not normally recognize as impossible. In this sketch I try to show the ways of using (or not-using) of this experience in literature. Many Polish writers emphasized the importance of ridicule in the description of the world of the camp, because "it sees sharper, it clearly draws", but that perspective often lacked in their books. However, there were writers (Grubinski and Wittlin) who put the world of Soviet slavery in satirical way, often in the form of "laughter through tears" (close to Bachtin's conception). There were also writers (Lipski and Mayewski) who dispassionately exposed the horror of the atrocity of the camp, they took the game with the absurd (close to Kayser's conception). Finally, there was a writer (Olszewski) who attempted to capture the entire Stalinist world as a grotesque.

Key words: a soviet camp; a grotesque; a satire; the totalitarianism; hyper-reality 